\title{
The Impact of Selected Factors on Apartments Market in Skarżysko-Kamienna
}

Abstract: The main purposes of this article were to find out which attributes of apartments in the Polish town of Skarżysko-Kamienna had the greatest influence on their unit price between January 2014 and April 2015, which of them had similar participation in apartments price formation, and to check the stability of apartments prices during the analyzed period of time. By using statistical methods, potential price-making attributes have been selected, and the stability of apartments prices on the local market has been checked.

Keywords: market analysis, premises, statistical analysis, random variable

* AGH University of Science and Technology, Faculty of Mining Surveying and Environmental Engineering, Department of Geomatics, Krakow, Poland 


\section{Introduction}

At the present time, one of the most-popular ways of investing money is the purchase of property. In professional articles connected with the property market or the economy, we can read about apartments price formation in the biggest Polish cities $[7,8,12]$. In large conurbations, the number of residents is still increasing, which causes a growth in the demand for apartments. In this publication, the author tried to answer the following question:

- How is the situation in smaller towns where the number of residents is below 100,000 (and still decreasing)?

- Which apartments are chosen by buyers?

- Which attributes of these apartments are the most in-demand?

To answer these questions, in the article, an attempt to select the attributes that might have the biggest influence on apartments prices in the analyzed market was undertaken.

Skarżysko-Kamienna is a town and municipality situated in the northern part of the Świętokrzyskie voivodeship. In the Fifteenth Century, there were bloomeries and amotherlode of iron. In 1923, Skarżysko-Kamienna gained its town charter. According to data from the $30^{\text {th }}$ of June 2014 , the town had a population of 47,354 residents [9]. With reference to the previous year, a decrease in the number of residents in Skarżysko-Kamienna could be noticed. Considering unemployment, the number of registered people without work was 6800 (according to data from April 2015), whereas the rate of unemployment was $25 \%$ [10]. At present, Skarżysko-Kamienna is an important industrial center and road and rail hub.

\section{Chosen Tools of Statistical Apartments Market Analysis}

Information obtained from the property market without a predefined search key is said to be random. In this connection, in statistical analysis concerning apartments price research that depends on their features, it is claimed to have to do with a multidimensional random variable where a component that describes prices is a clarified variable and dependent on many factors [5]. The remaining components that represent property attributes are independent interpretive variables.

In an analysis of large datasets, correlation analysis is a commonly applied practice whose results are presented very often as a correlation matrix [2,6]. Correlation is a relationship between variables, and a correlation coefficient has a value somewhere between -1 and 1 . A positive correlation is in a situation when growth in one variable causes growth in another. A negative correlation causes growth in one variable when a second variable decreases. A correlation at or about 0 represents a lack of dependence between two variables. Table 1 presents an exemplary scale that can be used to determine the strength of a correlation [1]. 
Table 1. Determination of correlation strength based on value of correlation coefficient

\begin{tabular}{|c|c||}
\hline Correlation coefficient & Strength of correlation \\
\hline \hline$|r| \epsilon(0.0-0.2]$ & very weak \\
\hline$|r| \epsilon(0.2-0.4]$ & weak \\
\hline$|r| \epsilon(0.4-0.6]$ & moderate \\
\hline$|r| \epsilon(0.6-0.8]$ & strong \\
\hline$|r| \epsilon(0.8-1.0]$ & very strong \\
\hline
\end{tabular}

Source: [1]

The way of analyzing trends in the apartments market is research on the average quarterly unit price. In this matter, it is necessary to divide the period of time from which the transactions come into quarters. Then, a test that compares the two average prices can be done according to the algorithm mentioned below.

To choose the appropriate test function for a verification hypothesis of the equality of average quarterly prices, standard deviations in price datasets (quarters, in particular) are compared by first using the Fischer-Snedecor statistic (2) at the same degree of relevance $(\alpha=0.05)$. These comparisons were made by checking the following assumptions:

$$
\begin{gathered}
H_{0}: \sigma_{X}^{2}=\sigma_{Y}^{2} H_{1}: \sigma_{X}^{2}>\sigma_{Y}^{2} \\
F=\frac{\hat{\sigma}_{X}^{2}}{\hat{\sigma}_{Y}^{2}}
\end{gathered}
$$

where $\hat{\sigma}_{X}^{2}, \hat{\sigma}_{Y}^{2}$ - estimators of variances for random samples $X$ and $Y$, respectively.

If there are no grounds to reject zero hypothesis $H_{0}$ about the equality of variances, the Student statistic is used to compare means:

$$
T=\frac{\hat{X}-\hat{Y}}{\sqrt{\frac{k_{X} \cdot \hat{\sigma}_{X}^{2}+k_{Y} \cdot \hat{\sigma}_{X}^{2}}{n_{X}+n_{Y}-2} \cdot \frac{n_{X}+n_{Y}}{n_{X} \cdot n_{Y}}}}
$$

where:

$\hat{X}, \hat{Y}$ - estimators of means for random samples $X$ and $Y$,respectively, $\hat{\sigma}_{X}^{2}, \hat{\sigma}_{Y}^{2}$ - estimators of variances for random samples $X$ and $Y$, respectively, $n_{X^{\prime}} n_{Y}$ - number of observations in particular samples where $k_{X}=n_{X}-1$, $k_{Y}=n_{Y}-1$. 
If there are grounds to reject a zero hypothesis about the equality of variances, the Cohran-Cox statistic (4) is used to compare means in the view of a small number of transactions (below 30) in particular quarters [1]:

$$
C=\frac{\hat{X}-\hat{Y}}{\sqrt{\sigma^{2}(\hat{X})+\sigma^{2}(\hat{Y})}}
$$

where:

$$
\begin{aligned}
& \hat{X}, \hat{Y} \text { - estimators of means for random samples } X \text { and } Y, \text { respecti- } \\
& \quad \text { vely, } \\
& \sigma^{2}(\hat{X}), \sigma^{2}(\hat{Y})-\text { accuracy of mean estimators. }
\end{aligned}
$$

\section{Property Base for Analysis}

Essential information for making our calculations was obtained from the Price and Property Valuation Registry, led by the Starost's Office of the Poviat in Skarżysko-Kamienna and from a conducted local vision. A dataset with information about 101 apartments that make property law was collected and tabulated by assigning them potential price-making attributes. This study comes from the period of January 2014 to April 2015 and is concerned with buildings on lands destined in zoning as lands of multi-family apartments housing. These attributes (with their assigned values) are presented in Table 2. Aside from features in Table 2, quantitative features that do not demand graduation (such as floor surface, utility room

\begin{tabular}{|c|c|}
\hline Attribute & Description of attributes \\
\hline Transaction date & number of months since December 2013 \\
\hline \begin{tabular}{|l} 
Limited \\
real rights \\
(easement, \\
mortgage)
\end{tabular} & $\begin{array}{l}0 \text { - yes - established on apartments } \\
1 \text { - no - apartments free from imposition }\end{array}$ \\
\hline $\begin{array}{l}\text { Apartments } \\
\text { location in } \\
\text { building: }\end{array}$ & $\begin{array}{l}0-\text { groundfloor } \\
1-\text { above } 6^{\text {th }} \text { floor } \\
2-4^{\text {th }}-5^{\text {th }} \text { floor } \\
3-2^{\text {nd }}-3^{\text {rd }} \text { floor } \\
4-1^{\text {st }} \text { floor }\end{array}$ \\
\hline Location & $\begin{array}{l}1 \text { - in distance } \geq 4 \mathrm{~km} \text { from town center } \\
2 \text { - in distance } \geq 3 \mathrm{~km} \text { and }<4 \mathrm{~km} \text { from town center } \\
3 \text { - in distance } \geq 2 \mathrm{~km} \text { and }<3 \mathrm{~km} \text { from town center } \\
4 \text { - in distance } \geq 1 \mathrm{~km} \text { and }<2 \mathrm{~km} \text { from town center } \\
5 \text { - in distance }<1 \mathrm{~km} \text { from town center }\end{array}$ \\
\hline
\end{tabular}
surface, number of rooms, and number of building floors) have been considered in the calculations.

Table 2. Description of apartments attributes 
Table 2 cont.

\begin{tabular}{|c|c|}
\hline Communication & $\begin{array}{l}0 \text { - poor - distance from the nearest bus stop is equal or greater than } 1000 \mathrm{~m} \text {; } \\
\text { frequency of bus runs from the nearest bus stop is maximally one per hour } \\
1 \text { - average - distance from the nearest bus stop is equal or greater than } 600 \mathrm{~m} \text { and } \\
\text { less than } 1000 \mathrm{~m} \text {; frequency of bus runs from the nearest bus stop is } 1-2 \text { per hour } \\
2 \text { - good - distance from the nearest bus stop is equal or greater than } 300 \mathrm{~m} \text { and less } \\
\text { than } 600 \mathrm{~m} \text {; frequency of bus runs from the nearest bus stop is } 2 \text { per hour minimum } \\
3 \text { - very good - distance from the nearest bus stop is less than } 300 \mathrm{~m} \text {; frequency of } \\
\text { bus runs from the nearest bus stop is } 3 \text { per hour minimum }\end{array}$ \\
\hline Surroundings & $\begin{array}{l}1 \text { - negative - lack of green areas, busy road in close proximity } \\
2 \text { - average - green areas, busy road in close proximity } \\
3 \text { - medium - green areas, playground, busy road in close proximity } \\
4 \text { - positive - green areas, sport facilities (playing fields) } \\
5 \text { - very positive - green areas, sport facilities (playing fields, skatepark, swimming } \\
\text { pool) }\end{array}$ \\
\hline $\begin{array}{l}\text { Building } \\
\text { condition }\end{array}$ & $\begin{array}{l}1 \text { - bad - building without insulation, staircase demands renovation } \\
2 \text { - average - building without insulation, staircase after reconditioning } \\
3 \text { - good - building with insulation, staircase after reconditioning, new front door } \\
4 \text { - very good - new building (from at least 2010) }\end{array}$ \\
\hline Lift & $\begin{array}{l}0 \text { - no - lack of lift in building } \\
1 \text { - yes - there is a lift in the building }\end{array}$ \\
\hline Balcony & $\begin{array}{l}0-\text { no } \\
1-\text { balcony } \\
2-\text { loggia } \\
3 \text { - terrace } \\
\end{array}$ \\
\hline Monitoring & $\begin{array}{l}0-\text { no } \\
1-\text { enclosed subdivision } \\
2-\text { monitoring } \\
3 \text { - enclosed subdivision and monitoring } \\
\end{array}$ \\
\hline $\begin{array}{l}\text { Window } \\
\text { exposition }\end{array}$ & $\begin{array}{l}0 \text { - north } \\
1 \text { - west } \\
2 \text { - east } \\
3 \text { - south } \\
4 \text { - southeast } \\
5 \text { - southwest } \\
6 \text { - north-south } \\
7 \text { - northeast, northwest } \\
8 \text { - east-west } \\
9 \text { - three directions of the world }\end{array}$ \\
\hline $\begin{array}{l}\text { Building } \\
\text { technology }\end{array}$ & $\begin{array}{l}1 \text { - slabs } \\
2 \text { - composite } \\
3 \text { - brick }\end{array}$ \\
\hline Parking-places & $\begin{array}{l}1 \text { - street parking } \\
2 \text { - fenceless parking place } \\
3 \text { - enclosed parking place } \\
4 \text { - covered parking place } \\
5 \text { - garage }\end{array}$ \\
\hline Land right & $\begin{array}{l}1 \text { - perpetual usufruct } \\
2 \text { - property }\end{array}$ \\
\hline
\end{tabular}




\section{Market Analysis}

\subsection{Pearson's Correlation Matrix}

As part of a market analysis, Pearson's correlation coefficients attribute-attribute and attribute-unit price have been calculated. The obtained values are presented as a correlation matrix in Table 3.

By using the color red, a strong correlation at least has been scored. This kind of relationship appeared in the following pairs of attributes: floor surface and number of rooms; location and communication; lift and monitoring; lift and number of building floors; and parking and monitoring. On the grounds of a correlation analysis, it is said that the above features play similar roles in unit price formation, and in the further process of valuation, there is the possibility of rejecting one of them from each analyzed pair. It is important to pay attention to the fact that such pairs of attributes as lift and monitoring and parking-places and monitoring are not dependent from themselves in practice, so the elimination of an attribute from each pair is inadvisable. In the case of pairs floor surface and number of rooms, location and communication, and lift and number of building floors, it is possible to eliminate those attributes that are less important in price formation, which shows the so-called importance of parts $k_{i}$. The important parts of apartments attributes in unit price formation have been calculated by using correlation coefficient attribute-unit price and the following formula [4]:

$$
k_{i}=\frac{r_{i}^{2}}{\sum_{i=1}^{m} r_{i}^{2}}
$$

where:

$r_{i}$ - correlation coefficient between attribute and unit,

$m$ - number of considered apartments attributes.

The important parts of particular features in property price formation are presented as follows (in descending order): monitoring (0.20), surroundings (0.17), parking-places (0.16), lift (0.14), building technology (0.10), number of building floors (0.07), building condition (0.06), balcony (0.04), land right (0.04), apartments location in building (0.01) and location (0.01). The influence of other attributes on price is said to be equal 0 .

On the grounds of the above calculations and the criterion of importance part at a level of 5\%, the crucial attributes in apartments unit price formation in Skarżysko-Kamienna are as follows (in descending order): monitoring (22\%), surroundings $(18 \%)$, parking $(18 \%)$, lift in the building $(16 \%)$, building technology $(12 \%)$, building condition (7\%), and number of building floors $(7 \%)$.

In references to a large apartments market (e.g., Krakow) according to data from a report published by Krakow City Hall in 2014, the following features played the most-important roles in transaction price: building technology, location, and floor surface [11]. 
Table 3. Pearson's correlation matrix

\begin{tabular}{|c|c|c|c|c|c|c|c|c|c|c|c|c|c|c|c|c|c|c|}
\hline Attribute & $\begin{array}{l}\text { Unit } \\
\text { price }\end{array}$ & $\begin{array}{l}\text { Floor } \\
\text { surface }\end{array}$ & $\begin{array}{l}\text { Utility } \\
\text { room } \\
\text { surface }\end{array}$ & $\begin{array}{l}\text { Number } \\
\text { of rooms }\end{array}$ & $\begin{array}{l}\text { Limited } \\
\text { real } \\
\text { rights }\end{array}$ & $\begin{array}{l}\text { Apartments } \\
\text { location in } \\
\text { building }\end{array}$ & $\begin{array}{c}\text { Number of } \\
\text { building's } \\
\text { floors }\end{array}$ & Location & Transportation & Surroundings & $\begin{array}{l}\text { Building } \\
\text { condition }\end{array}$ & Lift & Balcony & Monitoring & $\begin{array}{l}\text { Window } \\
\text { exposition }\end{array}$ & $\begin{array}{l}\text { Building } \\
\text { technology }\end{array}$ & Parking & $\begin{array}{l}\text { Land } \\
\text { right }\end{array}$ \\
\hline Unit price & 1.00 & 0.10 & 0.08 & 0.00 & -0.02 & -0.16 & 0.40 & 0.15 & -0.02 & 0.64 & 0.38 & 0.59 & 0.30 & 0.69 & 0.10 & 0.51 & 0.64 & 0.31 \\
\hline Floor surface & 0.10 & 1.00 & 0.13 & 0.63 & 0.17 & 0.03 & 0.29 & -0.06 & -0.15 & 0.21 & 0.21 & 0.32 & 0.12 & 0.33 & 0.16 & 0.12 & 0.33 & 0.20 \\
\hline $\begin{array}{l}\text { Utility room } \\
\text { surface }\end{array}$ & 0.08 & 0.13 & 1.00 & 0.03 & 0.08 & 0.19 & 0.05 & -0.32 & -0.31 & 0.07 & 0.07 & 0.18 & 0.08 & 0.14 & 0.17 & 0.16 & 0.11 & 0.33 \\
\hline $\begin{array}{l}\text { Number of } \\
\text { rooms }\end{array}$ & 0.00 & 0.63 & 0.03 & 1.00 & 0.15 & -0.08 & 0.13 & 0.17 & 0.18 & 0.04 & 0.08 & 0.14 & 0.11 & -0.01 & 0.12 & -0.24 & 0.14 & 0.04 \\
\hline $\begin{array}{l}\text { Limited real } \\
\text { rights }\end{array}$ & -0.02 & 0.17 & 0.08 & 0.15 & 1.00 & 0.08 & 0.06 & 0.02 & -0.05 & 0.04 & -0.07 & 0.07 & -0.08 & 0.08 & 0.28 & 0.07 & 0.04 & 0.11 \\
\hline $\begin{array}{l}\text { Apartments } \\
\text { location in } \\
\text { building }\end{array}$ & -0.16 & 0.03 & 0.19 & -0.08 & 0.08 & 1.00 & -0.25 & -0.08 & -0.03 & -0.04 & -0.13 & -0.19 & -0.18 & -0.06 & -0.08 & 0.07 & 0.03 & -0.13 \\
\hline $\begin{array}{l}\text { Number of } \\
\text { building floors }\end{array}$ & 0.40 & 0.29 & 0.05 & 0.13 & 0.06 & -0.25 & 1.00 & -0.24 & -0.20 & 0.30 & 0.39 & 0.86 & 0.26 & 0.39 & 0.22 & 0.05 & 0.19 & 0.39 \\
\hline Location & 0.15 & -0.06 & -0.32 & 0.17 & 0.02 & -0.08 & -0.24 & 1.00 & 0.73 & 0.24 & -0.22 & -0.23 & 0.05 & -0.06 & 0.04 & -0.08 & 0.09 & -0.25 \\
\hline Transportation & -0.02 & -0.15 & -0.31 & 0.18 & -0.05 & -0.03 & -0.20 & 0.73 & 1.00 & 0.02 & -0.17 & -0.22 & 0.09 & -0.18 & 0.05 & -0.29 & 0.03 & -0.17 \\
\hline Surround-ings & 0.64 & 0.21 & 0.07 & 0.04 & 0.04 & -0.04 & 0.30 & 0.24 & 0.02 & 1.00 & 0.28 & 0.44 & 0.21 & 0.58 & 0.04 & 0.38 & 0.44 & 0.12 \\
\hline $\begin{array}{l}\text { Building } \\
\text { condition }\end{array}$ & 0.38 & 0.21 & 0.07 & 0.08 & -0.07 & -0.13 & 0.39 & -0.22 & -0.17 & 0.28 & 1.00 & 0.45 & 0.33 & 0.47 & 0.08 & 0.16 & 0.22 & 0.28 \\
\hline Lift & 0.59 & 0.32 & 0.18 & 0.14 & 0.07 & -0.19 & 0.86 & -0.23 & -0.22 & 0.44 & 0.45 & 1.00 & 0.37 & 0.63 & 0.22 & 0.21 & 0.37 & 0.51 \\
\hline Balcony & 0.30 & 0.12 & 0.08 & 0.11 & -0.08 & -0.18 & 0.26 & 0.05 & 0.09 & 0.21 & 0.33 & 0.37 & 1.00 & 0.35 & 0.05 & 0.18 & 0.07 & 0.32 \\
\hline Monitoring & 0.69 & 0.33 & 0.14 & -0.01 & 0.08 & -0.06 & 0.39 & -0.06 & -0.18 & 0.58 & 0.47 & 0.63 & 0.35 & 1.00 & 0.22 & 0.54 & 0.60 & 0.33 \\
\hline $\begin{array}{l}\text { Window } \\
\text { exposition }\end{array}$ & 0.10 & 0.16 & 0.17 & 0.12 & 0.28 & -0.08 & 0.22 & 0.04 & 0.05 & 0.04 & 0.08 & 0.22 & 0.05 & 0.22 & 1.00 & -0.12 & -0.03 & 0.23 \\
\hline $\begin{array}{l}\text { Building } \\
\text { technology }\end{array}$ & 0.51 & 0.12 & 0.16 & -0.24 & 0.07 & 0.07 & 0.05 & -0.08 & -0.29 & 0.38 & 0.16 & 0.21 & 0.18 & 0.54 & -0.12 & 1.00 & 0.44 & 0.30 \\
\hline Parking & 0.64 & 0.33 & 0.11 & 0.14 & 0.04 & 0.03 & 0.19 & 0.09 & 0.03 & 0.44 & 0.22 & 0.37 & 0.07 & 0.60 & -0.03 & 0.44 & 1.00 & 0.09 \\
\hline Land right & 0.31 & 0.20 & 0.33 & 0.04 & 0.11 & -0.13 & 0.39 & -0.25 & -0.17 & 0.12 & 0.28 & 0.51 & 0.32 & 0.33 & 0.23 & 0.30 & 0.09 & 1.00 \\
\hline
\end{tabular}

Source: [11] 


\subsection{Research of Quarterly Variability of Unit Price}

The correlation coefficient between unit price and transaction data is 0.22 , which means a weak correlation according to Table 1 . However, the value of the calculated correlation strength does not provide for the possibility of conducting a wider analysis about the influence of time on apartments prices. Because of this fact, the analyzed period of time was divided into quarters, then the average transaction price and price standard deviation were calculated for each quarter. In this way, the stability of the local market was checked.

The following graphs (Fig. 1) present the dispersion of unit price about its mean in each of the analyzed quarters.
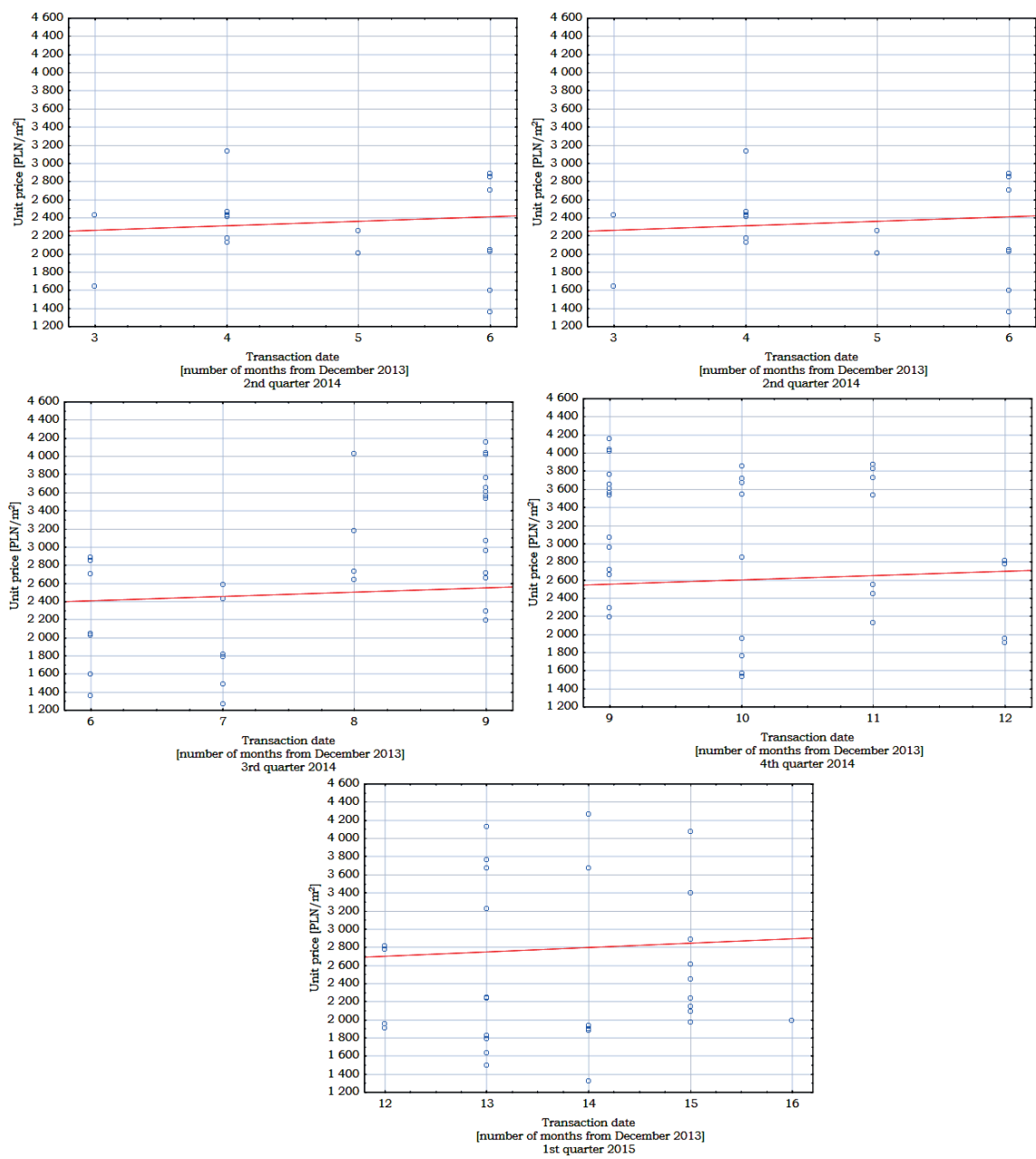

Fig. 1. Price dispersion in each analyzed quarter Source: [11] 
In the figures above, it can be noticed that, in the examined quarters, the smallest dispersion regarding average unit price is in January, February, May, and June 2014. In the remaining months, the differences between apartments prices and average quarterly prices (presented in Table 4) are clearly evident. The greatest value $\left(\approx 1700 \mathrm{PLN} / \mathrm{m}^{2}\right)$ was noticed in February 2015.

Estimators of means, standard deviations of apartments unit prices, and variability coefficients in successive quarters are tabulated in Table 4 . The greatest price difference was noted in the third quarter of 2014 and in the first quarter of 2015. In these time scales, there were the most transactions.

Table 4. Basic characteristics of price variable

\begin{tabular}{|c|c|c|c|c|}
\hline Quarter & $\begin{array}{c}\text { Average transaction price } \\
{\left[\mathrm{PLN} / \mathrm{m}^{2}\right]}\end{array}$ & $\begin{array}{c}\text { Number of } \\
\text { transactions }\end{array}$ & $\begin{array}{c}\text { Price standard } \\
\text { deviation [PLN/m²] }\end{array}$ & $\begin{array}{c}\text { Variability } \\
\text { coefficient }\end{array}$ \\
\hline \hline I & 1812.27 & 8 & 421.08 & 0.23 \\
\hline II & 2334.04 & 16 & 485.16 & 0.21 \\
\hline III & 2619.00 & 28 & 1078.96 & 0.41 \\
\hline IV & 2799.93 & 20 & 855.56 & 0.31 \\
\hline V & 2583.22 & 29 & 934.64 & 0.36 \\
\hline
\end{tabular}

Source: [11]

In Table 5, there are a verified hypothesis comparing quarterly data, values of the test functions, and critical values on the importance level of 0.05 .

Table 5.Verification of differences between average prices in successive quarters

\begin{tabular}{|c|c|c|c|}
\hline Verified hypothesis & Fischer-Snedecor test & $\begin{array}{l}\text { Test function } \\
\text { value }\end{array}$ & Critical area \\
\hline $\begin{array}{l}H_{0}: \mu_{I}=\mu_{I I} \\
H_{1}: \mu_{I}<\mu_{I I}\end{array}$ & $\begin{array}{c}H_{0}: \sigma_{I}=\sigma_{I I} H_{1}: \sigma_{I}<\sigma_{I I} \\
F=\left(\frac{485.16}{421.08}\right)^{2}=1.13 \\
F \notin(3.51 ;+\infty)\end{array}$ & $T=-2.5873$ & $\begin{array}{l}(-\infty ;-1.7171) \\
\text { Conclusion: there has been the } \\
\text { growth of price }\end{array}$ \\
\hline $\begin{array}{l}H_{0}: \mu_{I I}=\mu_{I I I} \\
H_{1}: \mu_{I I}<\mu_{I I I}\end{array}$ & $\begin{array}{c}H_{0}: \sigma_{I I}=\sigma_{I I} H_{1}: \sigma_{I I}<\sigma_{I I I} \\
F=\left(\frac{1078.96}{421.08}\right)^{2}=1.13 \\
F \notin(2.26 ;+\infty)\end{array}$ & $C=1.211$ & $\begin{array}{l}\qquad(-\infty ;-1.6448) \\
\text { Conclusion: there has not been } \\
\text { important price change }\end{array}$ \\
\hline
\end{tabular}


Table 5 cont.

\begin{tabular}{||c|c|c|c||}
\hline $\begin{array}{l}H_{0}: \mu_{I I I}=\mu_{I V} \\
H_{1}: \mu_{I I I}<\mu_{I V}\end{array}$ & $\left.\begin{array}{c}H_{0}: \sigma_{I I}=\sigma_{I V} H_{1}: \sigma_{I I I}<\sigma_{I V} \\
F \notin 5.35\end{array}\right)^{2}=1.59$ & $T=-0.6225$ & $\begin{array}{c}(-\infty ;-1.6787) \\
\text { Conclusion: there has not been } \\
\text { important price change }\end{array}$ \\
\hline$H_{0}: \mu_{I V}=\mu_{V}$ & $H_{0}: \sigma_{I V}=\sigma_{V} H_{1}: \sigma_{I V}<\sigma_{V}$ & & $\begin{array}{c}(1.6779 ;+\infty) \\
H_{1}: \mu_{I V}>\mu_{V}\end{array}$ \\
$F=\left(\frac{934.64}{855.36}\right)^{2}=1.19$ & $T=1.6663$ & $\begin{array}{c}\text { Conclusion: there has not been } \\
\text { important price change }\end{array}$ \\
\hline
\end{tabular}

Source: [11]

After conducting some statistical tests, it can be noticed that the average apartments unit price was higher about 521 PLN in the second quarter as compared to the first quarter. In successive time intervals, apartments prices were at a comparable level, which means that the analyzed market was stable from April 2014 to April 2015.

\section{Conclusions}

On the grounds of the conducted market analysis, the attributes that were crucial in apartments price formation in Skarżysko-Kamienna (which were said to be important for apartments buyers) were attributes connected with the infrastructure around the subdivision (monitoring, surroundings, and parking). Less influence on unit price had attributes concerning buildings where these apartments were sold (lift, building technology, building condition and number of building floors). It can be interpreted that, for people who buy apartments in Skarżysko-Kamienna, the most-important is landscaping (which can be associated with a sense of comfort).

From an analysis of the made graphs, demand for apartments purchase was relatively low in January, February, May, and July 2014. Because of this fact, their unit prices varied slightly from the average model price signified as a red line in Figure 1.

To sum up, there was growth in apartments prices from January 2014 to March 2014 in the analyzed market of Skarżysko-Kamienna. From April 2014 through April 2015, the apartments market was stable. Furthermore, the average 
quarterly unit price was about 2575.52 $\mathrm{PLN} / \mathrm{m}^{2}$. This price was definitely lower than the unit price in larger conurbations (e.g., in Krakow, the average transaction price in the aftermarket in 2014 was $6935 \mathrm{PLN} / \mathrm{m}^{2}$ [3]).

\section{References}

[1] Barańska A.: Elementy probabilistyki i statystyki matematycznej w inżynierii środowiska. Wydawnictwa AGH, Kraków 2008.

[2] Bełej M., Cellmer R.: Koncepcja oceny skali podobieństwa lokalnych rynków nieruchomości na potrzeby gospodarki przestrzennej. Studia i Materiały Towarzystwa Naukowego Nieruchomości, vol. 15, nr 3-4, 2007, pp. 23-34.

[3] BIP. Biuletyn Informacji Publicznej. Miasto Kraków, [on-line:] https://www.bip. krakow.pl/zalaczniki/dokumenty/n/134077/karta.

[4] Czaja J., Parzych P.: Szacowanie rynkowej wartości nieruchomości w aspekcie międzynarodowych standardów wyceny. Stowarzyszenie Naukowe im. Stanisława Staszica, Kraków 2007.

[5] Czaja J., Preweda E.: Analiza statystyczna zmiennej losowej wielowymiarowej $w$ aspekcie korelacji i predykcji. Geodezja - Akademia Górniczo-Hutnicza im. Stanisława Staszica w Krakowie, t. 6, z. 2, 2000, pp. 129-145.

[6] Dąbrowski J.: Zastosowanie wybranych metod statystycznych do analizy rynku nieruchomości. Statsoft Polska, [on-line:] http://www.statsoft.pl/Portals/0/Downloads/Zast_met_stat_analizy_rynku_nieruchomosci.pdf [access: 16.06.2015].

[7] Dittmann I.: Lokalne rynki mieszkaniowe w Polsce -podobieństwo pod względem zmian cen transakcyjnych oraz dostępności mieszkań. Studia i Materiały Towarzystwa Naukowego Nieruchomości, t. 20, nr 1, 2012, pp. 71-88.

[8] Krajewska M., Gaca R.: Preferencje nabywców nieruchomości na wybranych rynkach rodzajowych. Studia i Materiały Towarzystwa Naukowego Nieruchomości, t. 15, nr 3-4, 2007, pp. 35-42.

[9] Skarżysko-Kamienna. WIEM, darmowa encyklopedia, [on-line:] http://portalwiedzy.onet.pl/30354,,,skarzysko_kamienna,haslo.html [access: 16.06.2015].

[10] Statystyczne Vademecum Samorzadowca 2016. Gmina miejska Skarżysko-Kamienna. Powiat skarżyski, [on-line:] http://kielce.stat.gov.pl/vademecum/vademecum_swietokrzyskie/portrety_gmin/powiat_skarzyski/skarzysko_kamienna.pdf. (access: 16.06.2015).

[11] Śpiewak B.: Analiza rynku mieszkaniowego miasta Skarżysko-Kamienna wraz z wycena wybranego lokalu mieszkalnego. Akademia Górniczo-Hutnicza, Kraków 2015 [M.Sc. thesis].

[12] Żelazowski K.: Statystyczna analiza tódzkiego rynku nieruchomości. Studia i Materiały Towarzystwa Naukowego Nieruchomości, vol. 18, nr 1, 2010, pp. 133-144. 


\section{Wpływ wybranych czynników na rynek mieszkaniowy Skarżyska-Kamiennej}

Streszczenie: W publikacji podjęto próbę określenia, które atrybuty lokali mieszkalnych na terenie Skarżyska-Kamiennej miały największy wpływ na ich cenę jednostkową w okresie od stycznia 2014 do kwietnia 2015 roku, jakie z cech miały podobny udział w kształtowaniu cen mieszkań oraz czy w badanym czasie ceny ulegały istotnej zmianie. Dzięki zastosowaniu metod statystycznych wyselekcjonowano atrybuty potencjalnie cenotwórcze oraz sprawdzono stabilność cen mieszkań na badanym rynku mieszkaniowym w analizowanym okresie.

\section{Słowa}

kluczowe: analiza rynku, nieruchomości lokalowe, analizy statystyczne, zmienna losowa 